\title{
Kentsel Yenileme ile İlgili Yasal Düzenlemelerde Takdir Yetkisinden Gelen Esneklikler
}

\section{Flexibility from Discretion in Legal Regulations on Urban Renewal}

\author{
Sezen Tarakçı, ${ }^{1}$ (D) Şevkiye Şence Türk² \\ ${ }^{1}$ İstanbul Kent Üniversitesi Sanat ve Tasarım Fakültesi, Kentsel Tasarım ve Peyzaj Mimarlığı Bölümü, İstanbul \\ 2İstanbul Teknik Üniversitesi Mimarlık Fakültesi, Şehir ve Bölge Planlama Bölümü, İstanbul
}

\section{ÖZ}

Türkiye'de, kentlerin planlaması düzenleyici planlama sistemi ile sağlanmaktadır. Ancak, 2000'lerden itibaren planlama sistemindeki önemli değişiklikler, teorideki yapıdan uzaklaşılarak, pratikte esnek planlama sistemine doğru evrilmeye yol açmıştır. Benzer şekilde, kentsel yenileme uygulamalarında da esnek sistemin varlığı öne çıkmaktadır. Kentsel yenileme uygulamalarında esneklik iki farklı şekilde ortaya çıkmaktadır. Birincisi, kentsel yenileme uygulamalarının, 2004 yılından itibaren yürürlüğe giren özel amaçlı kanunlar ile gerçekleşmesidir. Kentsel yenileme ile ilgili özel amaçlı kanunlar, düzenleyici planlama sisteminin en temel özelliği olan hiyerarşi ilkesini, doğrudan devre dışı bırakmaktadır. Bu durum, kentsel yenileme uygulamalarının mevcut planlama sisteminin dışında gerçekleşmesini sağlamaktadır. Bu durum esnekliğin ortaya çıkmasına neden olmaktadır. İkincisi ise, kentsel yenileme ile ilgili yasal düzenlemelerdeki, yetkinin kullanımına ilişkindir. Kentsel yenileme uygulama süreçlerinde, gerek merkezi yönetime, gerekse yerel yönetimlere birçok konuda takdir yetkisi verilmiştir. Bu durum da esnekliğin şekillenmesinde doğrudan etkili olmuştur.

Anahtar sözcükler: Esneklik; kentsel yenileme; planlama sistemi; Türkiye.

\section{ABSTRACT}

In Turkey, urban planning is provided through the regulatory planning system. However, significant changes in the planning system since 2000 have triggered a shift in the planning system towards a flexible planning system in practice despite the structure in theory. A flexible system is also evident in urban renewal practices. Flexibility in urban renewal implementations occurs in two different ways. Firstly, urban renewal practices are applied in accordance with special laws that have been in effect since 2004. These special laws bypass the hierarchy that being a basic feature of the regulatory planning system. This situation causes to emerge urban renewal practices at outside of existing planning system, and hereby, a great deal of flexibility in urban renewal practices, in sense of giving of new development rights reveals. Second is related to the using of power in the legal regulations regarding urban renewal. With the legal regulations, both the central and local administrations discretionary power are given discretionary powerin urban renewal processes. This situation directly influenced the shaping of flexibility.

Keywords: Flexibility; urban renewal; planning system; Turkey.
Geliş tarihi: 17.02.2020 Kabul tarihi: I1.01.202।

Online yayımlanma tarihi: 02.03 .202 I

İletişim: Sezen Tarakçı

e-posta: sezen.tarakci@kent.edu.tr 


\section{Giriş}

Planlama, küreselleşme ve neoliberal politikalar gibi makro düzeydeki yapısal değişimlerden doğrudan etkilenmiştir (Munoz Gielen ve Tasan-Kok, 20 I0: I I0I). Ülkelerin finansal güçlerinin zayıflamasına karşılık ortaya çıkan bu yapısal değişimler, devletlerin geleneksel rolünde önemli değişiklikler ortaya çıkarmışır (Brenner ve diğ. 2010; Harvey, 2005; Brenner ve Theodore, 2002). Neoliberalleşme, güçlü özel sektör hakları, serbest piyasa ekonomisi ve ticarete dayalı kurumsal bir çerçeve içinde (Harvey, 2005) sosyal hayatın her alanında piyasa süreçlerinin devreye girmesi, yönetişimde rol oynamasına ve kontrolü elinde tutmasına yol açmışır (Peck ve Tickell, 2007). Neoliberal politik yaklaşımların etkisi ile, devletin yeniden yapılanması ile birlikte, 'kamu hizmetleri'nin doğası değişmeye başlamış ve devletlerin özel sektöre ve kamu-özel sektör ortaklıklarına güvenme eğilimi daha da artmıştır (Mercille ve Murphy, 20I5). $\mathrm{Bu}$ çerçevede izlenen 'piyasaların kuralıılaştırılması' ya da 'kamu sektörü ve hizmetlerin özelleştirilmesi' gibi yaklaşımlar, planlama ve planlamanın kurumsal yapısını şekillendiren yasal çerçeveyi önemli ölçüde değiştirmiştir (Türk, 20I7).

Son yıllarda planlama sistemlerinde, 'esneklik' ve 'kesinlik' ikilemine odaklanan tartışmalar yoğunluk kazanmıştır (Valtonen et al. 2017; Buitelaar ve Sorel, 2010: 983; Rivolin, 2008). Yasal olarak plan kararlarının bağlayıcı olduğu planlama sistemlerinde, kesinlik ön plandadır ve planlar ile getirilen yapılaşma hakları, planlar onaydıktan itibaren geçerlidir. Bu tür sistemlerde, plan kararları tüm taraflar açısından bağlayıcı sonuçlar içermektedir (Steele and Ruming, 2012, Rivolin, 2008). Bazı planlama sistemlerinde ise, plan kararları yasal açıdan bağlayıcı özellik taşımamaktadır. Bu tür sistemlerde, kesinlik yerine esneklik ön plandadır ve plan kararları yapılaşma haklarından daha çok stratejileri içermektedir. Bu tür sistemlerde, yapılaşma hakları, planlar üzerinde açık olarak tanımlanmadığı için, planlama kurumları ve arazi sahipleri (ya da girişimciler) arasında uzlaşma ve görüşme süreçlerine bağlı olarak ortaya çıkmaktadır (Rivolin, 2008). Bütün planlama sistemleri ortak biçimde, esneklik ve kesinlik özellikleri içermektedir. Ancak, bu özelliklerin dereceleri ülke sistemlerine göre farklılaşma göstermektedir. Bazı ülkelerde, örneğin, İngiliz planlama sisteminde, esneklik özelliği daha ön plandadır. Bu durum İngiliz planlama sisteminin tarihsel gelişimine bağlı olarak ortaya çıkmıştır (Booth, 2003; Booth, 1996). Diğer taraftan, düzenleyici planlama sistemine sahip çoğu ülkelerde ise, kesinlik özelliği ön plandadır (Munoz Gielen ve Taşan-Kok, 2010). Ancak, dünyada neoliberal ekonomik politikaların etkili olduğu 1990'। yıllardan itibaren, kesinlik özelliğinin ön planda olduğu planlama sistemlerinde esneklik arayışları artma eğilimi göstermiştir. Bu tür bir arayışın temelinde, bu dönemin özelliği olan artan kamu ve özel sektör yatırımlarının kolaylıkla planlama sistemine girişi sağlanması yer almaktadır (Heurkens ve Hobma, 20I4; Alfasi, 2006). Diğer taraftan, esnekliğin ön planda olduğu ülkeler ise, planlama sistemlerinde kesinlik oluşturma çabasına girmişlerdir (Avrupa Komisyonu, 1997). Bu durum, ülkelerin planlama sistemlerinin kesinlik ve esneklik arasında bir denge arayışına girdiklerini göstermektedir (Steele ve Ruming, 2012: 159).

Türkiye'de, düzenleyici planlama sistemi uygulanmaktadır. Ancak, 2000'lerden itibaren planlama sistemindeki önemli değişiklikler, teorideki yapıdan uzaklaşılarak, pratikte esnek planlama sistemine doğru evrilmeye yol açmıştır. Benzer şekilde, kentsel yenileme uygulamalarında da esnek sistemin varlığı öne çıkmaktadır (Özkan ve Türk, 2016: 36). Kuşkusuz, yasal düzenlemeler, kentsel yenileme ve kentsel yenilemenin kurumsal yapısının belirlenmesi ve işleyişi açısından önemli bir rol oynamaktadır.

Bu makalenin amacı, kentsel yenilemeyle ilgili yasal düzenlemelerde takdir yetkisi ile ortaya çıkan esnekliği ve sonuçlarını kentsel yenileme uygulamaları açısından analiz etmektedir. Bu makale, Türkiye'de 2004'ten günümüze kadar ortaya çıkan kentsel yenileme ile ilgili yasal araçlara bağlı olarak ortaya çıkan esnekliğin şekillenmesi ve derecesini, zaman içindeki içeriğindeki değişimi ve bunun doğrudan uygulamaya etkilerini göstermektedir.

Makalenin giriş bölümünün ardından ikinci bölümünde, Türkiye'deki düzenleyici planlama sisteminin özellikleri değerlendirilmektedir. Üçüncü bölümde, Türkiye'de planlama sisteminde ve kentsel yenileme uygulamalarında esnekliğin şekillenmesi ve zaman içerisindeki değişimi verilmektedir. Dördüncü bölümde, 2004'ten günümüze kadar ortaya çıkan kentsel yenileme ile ilgili yasalarda ortaya çıkan esneklik ve sonuçları karşılaştırmalı bir perspektif ile çeşitli örnekler üzerinden ele alınmaktadır. Beşinci bölümde ise, Türkiye'de kentsel yenileme alanlarında yasal kaynaklarla sağlanan esnekliğin yapısı analiz edilmekte ve sonuçları değerlendirilmektedir.

\section{Türkiye'de Planlama Sisteminin Özellikleri ve Esnekliğin Şekillenişi}

Ülkelerdeki planlama sistemleri, düzenleyici planlama sistemleri ve takdire dayalı planlama sistemleri olarak ayrımlaşmaktadır. Düzenleyici planlama sisteminde, plan, yasal bağlayıcıllğı olan, fiziki gelişmelere odaklı, takdir yetkisi kullanımını sınırlayan bir özellik taşırken, takdire dayalı planlama sisteminde plan, değişim yönetim aracı niteliğinde, takdir yetkisi kullanımına geniş imkan veren bir özellik taşımaktadır (Steele ve Ruming, 2012; Rivolin, 2008). Planlararası hiyerarşinin varlığı, kesinlik, katılıkdeğişmezlik, düzenleyici rol ve plan-uygulama bütünlüğü düzenleyici planlama sisteminin temel özellikleri iken, yatay ve dikey yerindenlik, esneklik, takdir yetkisi, uygulama farklılığ, stratejik rol ise takdir yetkisine dayalı planlama sisteminin temel özellikleridir (Steele ve Ruming, 2012; Rivolin, 2008). Türk planlama sistemi, teorik olarak düzenleyici planlama sistemi özelliğine göre şekillenmiştir (Türk, 2018; Özkan ve Türk, 2016: 36). 
Türkiye'de plan sisteminin en temel özelliklerinden biri, planlar arasında hiyerarşinin varlığıdır (Orta, 2005, Ersoy, 2000). Planlama sisteminde hiyerarşik ilişki, planların birbirini yönlendirme özelliği olarak ifade edilmektedir (Demir, 2009). Türkiye'de, 1985 yılında yürürlüğe giren, 3194 sayılı İmar Kanununda planlar arası hiyerarşik ilişkinin varlığına yer verilerek, farklı plan kademeleri oluşturulmuştur (Ünal, 20I5). Her bir alt ölçek planların bir üst ölçekteki planlardan daha fazla bilgi ve ayrıntıyı içermesi, kendi özgün ölçeğinin gerekli kıldığı yeni bilgi ve verileri de kapsayan, ancak bir üst ölçeğin ana kararlarını koruyan bir yapıda olması gerekmektedir (Ersoy, 2000: 37). Bununla birlikte, bu hiyerarşik ilişki ile şekillenen yapının, kentlerin dinamik yapısını karşılayamadığı yönünde eleştiriler de sık olarak ifade edilmektedir (Ünlü, 2009; Ünlü, 2006; Gedikli, 2004). Çünkü, uygulamada kamu yönetimleri tarafından planlar arasında hiyerarşinin varlığının çoğunlukla önemsenmediği ve özellikle de neoliberal politikaların etkisiyle kentsel mekânın, planlar yerine parçacıl projelerle geliştiği sık olarak vurgulanmaktadır (Özden, 20I3, Kentleşme Şurası, 2009: 274). 1985 yılında yürürlüğe giren, 3194 sayılı İmar Kanunundaki, imar anlayışı, yüksek düzeyde 'kesinliğe' dayanan, ulusal düzeyde tüm kentlere aynı standartları getiren bir düzenleyici sistem özelliği göstermektedir (Ünlü, 2006: 64). Diğer taraftan, planlar, onaylandıktan sonra askı süresinin bitmesi ile kesinleşmesine bağI olarak zorunlu hukuksal bir belgeye dönüşmektedir (Ünal, 2015; Keleş, 2012). Bunun anlamı ise, planların tüm taraflar açısından bağlayıcı olmasıdır. Ancak ülkemizde, teorik yapının kesinlik özelliğine rağmen, proje temelli yaklaşımların giderek ağılık kazanması, planlama sisteminde esnekliğe yönelik bir eğilimi ortaya çıkarmaktadır (Özkan ve Türk, 20l6).

Türk planlama sisteminin kurumsallaşmaya yönelik geçmişi incelendiğinde; planlamanın kurumsal yapısının kentsel alanların sorunlarını karşılama açısından yetersiz olduğu söylenebilir. Özellikle, Cumhuriyet döneminde başlayan "modern, bilinçli, sistemli ve gayretli" olarak ifade edilebilecek kentleşme hareketleri, 1950'lere gelindiğinde, yoğun göçlerle birlikte hızlanmış ve planlamanın kurumsal yapısı bu dönemin sorunlarını çözmede yetersiz kalmıştır (Özden, 2006: 219). Kent çeperlerinde gecekonduların birbiri ardına ortaya çıkması da bu dönemlere denk düşmektedir. 1970'lerin sonundan itibaren ise, kentsel gelişme artan bir biçimde özel sektör dinamikleri tarafından şekillendirilmiştir. Özel sektör zaman içinde gittikçe aktif rol üstlenirken, kamu sektörü gittikçe daha pasif bir rol üstlenmiştir (Taşan-Kok, 2008: 185). Buna bağlı olarak, 1980'li yıllar, gecekondulara hizmet götürme ve bu alanların yasallaştırılma dönemi olmuştur. Başta 1984'te yürürlüğe giren 298I sayılı İmar Affı Kanunu ve 1986 tarihli 3290 sayılı değişiklik olmak üzerekentsel gelişmenin ıslah imar planları ile yönlendirilmesine neden olmuştur (Özden, 2013: 436).

1980'lerde neoliberal politikaların uygulanmaya başlanması ile, kentsel planlamanın yasal ve kurumsal yapısında da önemli ölçüde değişimler olmuş ve planlamada kuralsızlaştırmaya gidilmiş- tir (Balaban, 20I2). Türkiye'de kentsel ve bölgesel politikaların belirlenmesinde merkezi planlama her zaman önemli bir rol oynasa da, neoliberal ekonomik dönüşüm sürecinde, planlamada yeni kurumsal düzenlemelere gidilerek, yerel düzeyi ön plana çıkaran bir değişim sürecine girilmiştir. Bununla birlikte, yapılan bu düzenlemeler de, esnek olmayan, kuralcı ve katı bir planlama yaklaşımını benimsemiştir. Bu durum, giderek artan yatırım baskısı ile planlama arasında çatışmayı ortaya çıkarmıştır (Taşan Kok, 2006: 327). Planlama sistemi, kentsel mekândaki değişimin yönetilmesi için imar anlayışına dayalı bir çerçeve sunmaktadır. Kent ölçeğinde 'nazım imar planları', alana yönelik olarak 'uygulama imar planları' ile belirlenen imar anlayışının, esneklikten uzak ve katı olduğu literatürde sık olarak vurgulanmıştır (Ersoy, 2000; Ünlü, 2006; Taşan Kok, 2006; Keleş, 20I2; Özden, 20I3; Özkan ve Türk, 2016). Bu anlamda, planlar kentsel mekânda değişimin yönetilmesi sürecinde, gerekli olan esnekliği, yorumlama potansiyelini ve katılım olanaklarını sunmaktan uzaktır (Ünlü, 2006: 75). Planlama sisteminde ortaya çıkan bu durum, çoğu kez mevcut bürokratik kısıtlamalar ve yerel politik ilişkiler ile aşılmaya çalışılmıştır (Özkan ve Türk, 20I6).

1990'lı yıllarda ise, neoliberal ekonomik politikaların etkisiyle, kent mekânında değişimler başlamış, büyük ofis yapıları, plazalar, alışveriş merkezleri kent mekânında kapsamlı dönüşümlere yol açmıştır (Güzey, 2016; Özden, 2013). Örneğin, İstanbul'da konut alanlarında ve konutların kullanımında da bazı değişiklikler gerçekleşmiş, ikinci Boğaz Köprüsünün ve çevre yollarının yapımı ile birlikte, bu akslar üzerinde finans merkezleri inşa edilmiştir (Özus ve diğ., 20I I; Ergün, 2006). Ayrıca bu dönemde yanlış kentleşme politikaları ile, kentsel alanlarda parçaçıl arsa geliştirme süreçleri artmış, buna karşılık merkezi ve yerel yönetimler, kentsel arsa geliştirmede ve konut yapımında yetersiz kalmış, kentlerdeki yapıların imar planlarına uygunluğunu denetleyecek mekanizmalar oluşturulamamıştır. Bunun sonucunda, yatay olarak tek katlı olan yasadışı yapılaşma bu kez düşey olarak çok katlı yeni bir yasadışı yapılaşmaya dönüşmüştür (Köktürk ve Köktürk, 2007: 6). Tüm bunlar, ortaya çıkan yapılaşmış çevreye yönelik kentsel yenileme gereksinimini artmıştır.

2000'li yıllara gelindiğinde ise, özellikle Marmara ve Düzce Depremlerinin etkileri ile de, afetler karşısında risk azaltımı araçlarından biri olarak kentsel yenileme gündeme gelmiştir (Kuyucu ve Ünsal, 2010). Özellikle metropoliten alanlarda, hem eskiyen yapılaşmış çevrenin yenilenmesi, hem de deprem riskli yerleşim alanlarının yeniden yapılandırılması sorunu bulunmaktadır. Bu nedenle, kentsel yenileme, kentsel gelişmeye yön veren önemli bir politika haline gelmiştir. Yerel yönetimler, kamu-özel sektör işbirliği ile geliştirilen, yüksek rantlı alanlarda uygulamaya konan ve ıslah-imar planlarına tek alternatif olarak görülen özel kentsel yenileme projeleri uygulamalarına başlamıştır (Genç, 2014: 18). Bununla birlikte, proje temelli planlama sistemini uygulayan ülkelerde olduğu gibi, yerel yönetimler ile özel sektör arasındaki görüşme ve uzlaşma süreçleri de sistemde tanımlanmış olmadığından (Türk, 20I8), kentsel yenile- 
me sonrasında elde edilecek çıktılar kontrol edilememektedir (Özkan ve Türk, 2016). Ancak, toplumsal alanın devingenliği karşısında imar planlarının katı ve durağan çerçevesi kentsel mekân üretilmesi konusundaki yetersizliği (Ünlü, 2006: 64), proje temelli sistemin ilerlemesine izin vermiştir. Bu durum, özellikle kentsel yenileme ile ilgili olarak çıkarılan yasal mevzuat ile de desteklenmiştir.

Son yıllarda, Türk planlama sisteminde, planlama kurumları, kentsel gelişmeyi tanımlamak, yönlendirmek ve denetlemek amacından saparak, kenti bütün olarak görmekten uzaklaşan ve küçük kent parçalarına yönelik olarak karar geliştiren bir yaklaşım benimsemektedir. Bu durum, gittikçe esnek ve proje temelli bir yaklaşımı öne çıkarmaktadır. Bu nedenle, planlama, piyasa taleplerine göre değişen ve esnek bir uygulama aracına dönüşmektedir (Özden, 20I3; Taşan Kok, 2006: 327). Neoliberal ekonomik politikaların giderek ağırlık kazanması ve hükümetin izlemiş olduğu 'konut odaklı inşaat' politikası ile (Balaban, 20I2), kentler üzerinde giderek artan yatırım baskısı altında inşaat patlaması ortaya çıkmışır. Böylelikle, artık yatııımcılar için kentsel alanların yapılaşmış kısımları da, kentin gelişme alanları kadar ilgi görmeye başlamıştır (Türk ve Korthals Altes, 2010; Ünsal ve Türk, 2014). Kentiçi alanların yenilenmesinde özel sektör ve kamu sektörü ortaklıkları yoğun biçimde ortaya çıkmaya başlamıştır. Özellikle, İstanbul'da özel sektör tarafından çok sayıda büyük ölçekli, karma kullanımlı, yeniden geliştirme prestij projeleri önerilmiştir (Kentleşme Şurası, 2009: 293).

\section{Kentsel Yenileme İle İlgili Yasal Düzenlemelerdeki Esneklik}

Genel olarak bakıldığında esneklik; politik, kurumsal- yönetimsel ve plan yapımıyla ilgili yasal süreçlerin değişime uğramasının hem sebebi hem de sonucu olarak gelişmiştir. Plan yapımı ve uygulaması süreçlerine, kent arazisi ile arazi üzerindeki hizmetlerin sağlanması ve gelişimine kadar her aşamada kamu-özel ortaklığının dahil olması, esneklik kavramını da etkilemiştir. Bu açıdan bakıldığında, kent planlamasında neo-liberal politikalar ile oluşan kamu ve özel sektör aktörleri arasındaki denge, ülkelerin özgün planlama yaklaşımları, ekonomik süreçler, kamunun finansal gücü ve özel sektörün yatırım talebi gibi konular esneklik olgusuna dair yönelmeyi etkilemektedir (Özkan, 20I2: 24). Genel bir çerçeve içinde, kentsel yenileme, farklı nedenlerden dolayı zaman süreci içinde eskimiş, yıpranmış ya da terkedilmiş, kentsel dokunun, günün sosyo-ekonomik ve fiziksel koşulları göz önünde tutularak dönüştürülmesi ve yeniden canlandırılarak kente kazandırılması olarak ifade edilebilmektedir (Özden, 200I: 257). Kentsel yenileme ile ilgili yasal düzenlemelerde takdir yetkisinden gelen esneklik; "planlama yaklaşımı ile ortaya çıkan esneklikler" ve "karar yetkisinden ortaya çıkan esneklikler" olmak üzere iki farklı şekilde açıklanabilir:

Birincisi, kentsel yenileme uygulamalarının plan temelli bütünsel bir yaklaşım yerine proje temelli bir yaklaşımla, düzenleyici planlama sisteminin dışında kalmasıdır. Kentsel yenileme uygulamaları, 2004 yılından itibaren yürürlüğe giren özel amaçlı kanunlar' ile gerçekleşmektedir. Bu özel amaçlı kanunlar, düzenleyici planlama sistemi ile ortaya çıkan planlama sistemindeki hiyerarşiyi doğrudan devre dışı bırakmaktadır. Bu durumda kentsel yenileme uygulamalarının, planlama sistemi içerisinde belirlenen kararlara uyum sağlayamadığı açıktır. Örneğin, kentsel yenileme uygulamalarında, proje alanının yakın çevresindeki alanların kullanım fonksiyonu, sosyal ve donatı alanı dengesi ve yoğunluğu dikkate alınmamaktadır (Ocakçı ve diğ.,2017). Diğer taraftan, kentsel yenileme alanlarında benimsenen proje temelli yaklaşım, düzenleyici planlama sisteminde olduğu gibi tüm yapılaşma kararlarının belirlendiği ayrıntılı bir planlamadan daha çok, plan notları ile belirlenen bir plan sistemi ortaya çıkarmaktadır. Türkiye'de fiziki plan kademelerinin ve plan hiyerarşisinin olduğu katı plan temelli sistem bulunmaktadır. Ancak bu katılık plan notları ile esnetilebilmektedir (Türk, 2018; Ünlü, 2006; Ersoy, 2000). Özellikle kentsel yenileme uygulamaları, plan notları üzerinden yürütülmektedir. Son yasal düzenleme olan 6306 sayılı kanuna göre, kentsel yenileme alanlarının belirlenmesinde, alanlara ilişkin planların yapılmasında ve onaylanmasında, alanda yapılacak yapılara ruhsat verilmesinde Çevre ve Şehircilik Bakanlığı yetkilidir. Böylelikle, kentsel yenileme alanı ilan edildikten sonra, mevcut durumda düzenleyici planlama sistemine göre hazırlanmış olan imar planları ve bu imar planları ile verilen hakları geçerliliğini kaybetmektedir. Bu durum ayrıca, plan bütününde delinmelere yol açarak aynı ilçede hatta aynı mahallede planlamadan yerel yönetim veya merkezi yönetimin sorumlu olması ayrımını getirmektedir. Bu durum planlama sistemindeki hiyerarşiyi etkilediği kadar planların bütünlüğünü de etkilemektedir. Sosyal ve teknik altyapı alanlarının dağılımı, nüfus yoğunluğu, ulaşım yatırımları gibi kentin tamamını etkileyen konular parçacıl bir şekilde farklı yasal dayanaklar ile planlanmaktadır. 6306 sayılı kanun ile birlikte planlarda uyulacak standartların da bakanlık tarafından belirlenmesi özellikle sosyal ve teknik altyapı alanlarının planlanmasında önemli esneklikler sağlamaktadır.

İkincisi, kentsel yenileme ile ilgili yasal düzenlemelerde, gerek merkezi yönetime gerekse yerel yönetime kentsel yenileme alanının belirlenmesinden, uygulamanın tamam-

2004 tarihli ve 5104 sayılı Kuzey Ankara Girişi Kentsel Dönüşüm Projesi Kanunu

2005 tarihli ve 5366 sayılı Yıpranan Tarihi ve Kültürel Taşınmaz Varlıkların Yenilenerek Korunması ve Yaşatılarak Kullanılması Hakkında Kanun

2005 tarihli ve 5393 sayılı Belediye Kanununun 73. maddesi ile söz konusu maddede değişiklik yapan 2010 tarihli ve 5998 sayılı Belediye Kanununda Değişiklik Yapılmasına İlişkin Kanun

2012 tarihli ve 6306 sayılı Afet Riski Altındaki Alanların Dönüştürülmesi Hakkında Kanun. 
lanmasına kadar birçok konuda takdir yetkisi verilmiş olmasıdır. Takdir yetkisi, Türk İdare Hukuku bakımından ayrı bir öneme sahiptir. İdari yaşamın gerekçelerinden kaynaklı olarak, idarenin az veya çok takdir yetkisine sahip bulunması zorunludur (Yayla, 1990: 77). Takdir yetkisi, idareye, işlemin sebebini, konusunu, zaman ve yerini belirlemek; çeşitli çözümlerden birini seçmek; işlem yapmak ya da yapmamak konusunda verilen hareket serbestisidir (Seçkin ve Üstün, 20I5). Kentsel yenileme uygulamalarının en temel aktörlerini Merkezi Yönetim [Çevre ve Şehircilik Bakanlığı, Toplu Konut İdaresi Başkanlı̆̆ı (TOKi)] ve Yerel Yönetimler (Büyükşehir Belediyeleri, Belediyeler, İ Özel İdareleri) oluşturmaktadır. Yerel yönetimler, özellikle büyük ölçekli konut üretiminde hem düzenleyici hem de doğrudan yatırımcı rolü oynamaktadır. Belediyelerin doğrudan yatırımcı olarak rolleri; konut projelerini doğrudan kendi şirketleri aracılığıyla uygulamak, kâr amaçlı projeler yapmak ve çeşitli ortaklıklar kurmak şeklindedir. Düzenleyici olarak rolleri ise; konut alanları için parseller üretmek, planlama ve onaylama, kamulaştırma, satın alma gibi kamu müdahale araçlarını kullanma hakkıdır (Türk ve Korthals Altes, 2010: 189). Ülkemizde farklı dönemlerde yürürlüğe giren af kanunları, aynı mahalle içerisinde bile farklı mülkiyet biçimlerinin oluşmasına yol açmıştır. Kentsel yenileme uygulamaları, 'tapusu olanlar', 'tapu tahsis belgesi olanlar', 'muhtar belgesi olanlar' ve 'hiçbir belgeye sahip olmayanlar' şeklinde mülkiyetin yasal statüsüne dayalı bir sistem üzerinden kurgulanmaktadır (Şen ve Türkmen, 2014: 169). Bu durum, kentsel yenileme uygulamalarının temelini oluşturan mülkiyet konusunda yönetimlere hem değerleme hem de kamulaştırma gibi önemli konularda takdir yetkisi vermektedir. Bu da, kentsel yenileme uygulamalarında geniş bir esneklik sağlamaktadır. Bununla birlikte, 2004 yılında 5162 sayılı kanunla TOKI'ye kentsel yenileme alanlarında önemli yetkiler verilmiştir. $\mathrm{Bu}$ yetki, gerek gecekondu alanlarında, gerek kendi mülkiyetinde bulunan alanlarda, gerekse toplu konut alanı ilan edilmiş alanlarda geçerlidir. Kentsel yenileme pratiklerinde, çöküntüye uğramaya başlamış kent merkezlerinde yaşayan düşük gelirli kesimlerin, kent merkezlerine uzak alanlarda TOKI tarafından üretilen konut alanlarına yerleştirilmesi bu dönemin yerleşik politikalarından biri haline gelmiştir. 2012 yılından itibaren ise 6306 sayılı kanunla, Çevre ve Şehircilik Bakanlığı kentsel yenileme uygulamalarının temel aktörü olmuştur. Öyle ki, kentsel yenileme projesinin başlangıcından bitimine kadar yapılacak tüm uygulamalarda Bakanlık tek yetkili konumdadır (Gür ve Türk, 20I4: 636).

Türkiye'de kentsel yenilemenin çıkış noktası olarak en çok deprem riski ön plana alınmaktadır. İstanbul'da deprem riski ile ilgili olarak yapılan analizlerin sonucunda hazırlanan JICA Raporu'nda (IBB-JICA, 2002: 32) yeniden geliştirme veya büyük oranda güçlendirme gereken dört yüzün üzerinde mahalle belirlenmiştir. Tarakçı ve Türk (20I5: I572) İstan- bul bütünü için yaptıkları araştırmada ilan edilmiş olan riskli alanların bulunduğu ilçelerin hem sıvılaşma potansiyeli, hem heyelan, hem de bina hasar görülebilirlik ve bina durumları açısından JICA Raporunda (2002) sıralanan önceliklendirmelerle uyuşmadığını, bu noktada kanunun gerçek amacından uzaklaştığını ortaya koymuşlardır. Bunun olabilmesine olanak tanıyan ise, kentsel yenileme ile ilgili yasalarla yönetime verilen takdir yetkisidir.

Yukarıda belirlenen yasal düzenlemelerin ortak noktası, planlamayı proje uygulamalarını güçleştiren bir engel olmaktan çıkarıp, esnek ve piyasa dinamiklerini göz önüne alarak mekânsal gelişimi düzenleyen bir yapıda yeniden tanımlamaktır. Bu doğrultuda, söz konusu kanunlarla kentsel yenileme uygulamalarına gelen esneklikler aşağıda kentsel yenileme alanın belirlenmesi ve onaylanması, mülkiyetin değerlendirilmesi, planlama yetkileri, kamulaştırma, mülkiyetin dağıtımı ve sosyal yapı konularında ayrıntılı olarak incelenmektedir.

\section{I04 Sayılı Kuzey Ankara Girişi Kentsel Dönüşüm Projesi Kanununda Ortaya Çıkan Esneklikler}

2004 yılında yürürlüğe giren 5104 sayılı Kuzey Ankara Girişi Kentsel Dönüşüm Projesi Kanunu ile, Kuzey Ankara Girişi Kentsel Dönüşüm Projesi uygulama alanlarının fiziksel yapısının iyileştirilmesi, çevre görüntüsünün geliştirilmesi, güzelleştirilmesi ve daha sağlıklı bir yerleşim düzeninin sağlanması ile kentsel yaşam düzeyinin yükseltilmesi amaçlanmaktadır.

Kuzey Ankara Girişi Kentsel Dönüşüm Projesi'nin öne çıkan özelliği; Ankara'nın protokol yolu ve kuzey kent girişi konumunda olan bölgeye başkentlik işlevine yakışır bir kimlik kazandırma amacı ile gerçekleştirilmesidir (Kütük İnce, 2006: 169). Proje, toplam 1580 hektarlık bir alana sahiptir ve proje ile 70.000 kişilik bir nüfus öngörülmüştür. Projenin etaplar halinde yapılacağı, öncelikli etabın ise 400 hektarlık alanı kapsadığı ifade edilmektedir. Öncelikli etap kapsamında 18.000 adet konut, 47 ha özel rekreasyon alanı, 2 adet otel ve kongre merkezi, 18 ha gölet alanı, 3 km uzunluğunda yol, tünel ve viyadük yer almaktadır (www.toki.gov.tr). Proje, kamu-özel sektör ortaklığı çerçevesinde, Büyükşehir Belediyesi ile TOBAŞ isimli şirketin işbirliğini içermektedir (Kütük İnce, 2006: 169).

Türkiye planlama sisteminin kademelenmesi ve yetki hiyerarşisine göre, büyükşehir statüsünde olan kentlerde, uygulama imar planı ilçe belediyesi tarafından, nazım imar planı ise, büyükşehir belediyesi tarafından hazırlanmaktadır. Kanun ile, her ölçekteki imar planını yapma yetkisi Ankara Büyükşehir Belediyesi'ne verilerek planlama sistemindeki yetki hiyerarşisine müdahale edilmiştir. Ayrıca, mevcut planların devam edip etmeyeceği veya yeniden plan yapılıp yapılmayacağı hususunda belediyeye takdir yetkisi verilerek, esneklik sağlanmıştır. Bu kanuna göre; her türlü eski imar hakları geçerliliğini yitirecek 
olup yeni imar hakları, hazırlanacak olan imar planına göre yeniden belirlenecektir. Kanun bu yaklaşımı ile parçacıl olarak yapılan özel amaçlı planların kentin bütünü için yapılan imar planlarının önüne geçmesini sağlamaktadır. Bu kanundan sonra çıkan kentsel yenileme ile ilgili özel amaçıı kanunlar aynı yaklaşımı taşımaya devam etmektedir.

Bu kanuna göre yapılan proje, malikler ve hak sahipleri ile yapılan anlaşmalar çerçevesinde uygulanmaktadır. Anlaşma sağlanamayan hallerde ise, gerçek kişilerin ve özel hukuk tüzel kişilerinin mülkiyetinde bulunan gayrimenkuller belediye tarafından kamulaştırılabilmektedir. Kanunda 'tapu sahipleri', 'tapu tahsis belgesi olanlar' ve 'tapu tahsis belgesi olmayan ancak I Ocak 2000 tarihinden önce yapıldığını belgeleyen ruhsatsız yapı ve gecekondu sahipleri' hak sahibi olarak tanımlanmaktadır. Böyle bir ayırım, af kanunlarından sonra ilk kez yasal düzenlemelere girmiştir. Yapılan projeden belediye ile anlaşma sağlayan tapu sahipleri işyeri ve konut edinebilmekte, tapu tahsis belgesi sahibi olanlar ise konut edinebilmektedir. Ancak diğer gecekondu sahiplerinin yapılacak projeden konut edinip edinemeyeceği açıklanmamıs olup, konut bedellerinin 2985 sayılı Toplu Konut Kanunu hükümlerine göre belirlenerek Toplu Konut İdaresi Başkanlığı tarafından yürütüleceği ifade edilmiştir. Bu duruma göre, projeden hak sahiplerine dağıtımda belediye meclisi yetkili olup, tapu sahibi olunması, tapu tahsis belgesindeki alanının $400 \mathrm{~m}^{2}$ olması, tapu tahsis belgesindeki alanının $400 \mathrm{~m}^{2}$ den az olması şeklinde kategori edilmektedir: Birincisi, Belediye ile anlaşma yapan tapu sahiplerine, mülklerinin Belediye Meclisince belirlenen büyüklükte olması kaydıyla; bölgede yapılacak işyeri ve konutlardan verilmektedir. İkincisi, tapu tahsis belgesindeki arsa alanı 400 $\mathrm{m}^{2}$ olan hak sahiplerine Belediye Meclisi tarafından belirlenen büyüklükte bir adet konut verilmektedir. Üçüncüsü ise, tapu tahsis belgesindeki alan $400 \mathrm{~m}^{2}$ 'den az olanlar konut sözleşmesi ile borçlandırılmaktadır. Buradan da anlaşılmaktadır ki mülkiyetlerin yeniden dağııımına ilişkin Belediye Meclisine büyük bir takdir yetkisi verilmiş olup, böylelikle bu konuda esneklik sağlanmıştır (Tarakçı ve Türk, 20I7).

\section{Sayılı Yıpranan Tarihi ve Kültürel Taşınmaz Varlıkların Yenilenerek Korunması ve Yaşatılarak Kullanılması Hakkında Kanun ile Ortaya Çıkan Esneklikler}

2005 yılında sit alanı olarak ilan edilen bölgeler ile bu bölgelere ait koruma alanlarında yapılacak yenilemelere ilişkin olarak, 5366 sayııı Yıpranan Tarihi ve Kültürel Taşınmaz Varlıkların Yenilenerek Korunması ve Yaşatılarak Kullanılması Hakkında Kanun kentsel yenileme uygulamalarını yürütmede önemli bir yasal araç olarak yürürlüğe girmiştir.

Ülkemizde kentlerin tarihi merkezlerinde yer alan ve özel fiziksel niteliklere sahip yıpranmış konut alanları bütün kent- lerde giderek önem kazanmaktadır. Kentin tarihi bölgelerinde yer alan yıpranmış konut alanları üst gelir grupları tarafından terk edilmiş ve yoksulların sığınağı haline gelmiştir. Bu bölgeler, bir yandan ucuz barınma olanağı sunarken, diğer yandan merkezi konumları nedeniyle işyerlerine kolay ulaşım sağlamaktadır. Bu alanlar, 1990'lardan itibaren çeşitli dönüşümlerden geçmiştir. Kent merkezlerinde sosyo-mekânsal dönüşümün yaşandığı bu bölgeler, rant potansiyeli nedeniyle yatırımcıların ilgisini çekmiş ve yerel yönetimlerin de desteğiyle yeniden canlandırma projelerinin en önemli hedefi haline gelmişlerdir (Türkün ve Sarıoğlu, 20|4: 267).

Bu kanun ile belediyelere; yenileme proje alanlarının belirlenmesinde, projenin hazırlanmasında ve projenin uygulanmasında çok geniş yetkiler tanınmaktadır. Yenileme alanları; il özel idarelerinde il genel meclisinin ve belediyelerde belediye meclisinin üye tam sayısının salt çoğunluğunun kararı ile belirlenmekte olup, il genel meclisi/belediye meclisince alınan kararlar (Büyükşehirlerde ise ilçe belediye meclislerince alınan kararlar, büyükşehir belediye meclisince onaylanması üzerine) Çevre ve Şehircilik Bakanlığının teklifi ile Bakanlar Kuruluna sunulmaktadır. 02.07.20I8 tarihli ve 700 sayılı KHK ile Bakanlar Kurulunun yetkisi Cumhurbaşkanı'na verilmiştir. Alanın belirlenmesinde ilk yetkili yerel yönetimler olmasına rağmen, merkezi yönetimin kararı ile uygulanabilmektedir. Örneğin, İstanbul, Beyoğlu ilçesinde Tarlabaşı semti 20 Şubat 2006 tarihinde Bakanlar Kurulu kararı ile 'Yenileme Alanı' olarak ilan edilmiştir. Anılan kararla yirmi bir yapı adası kentsel yenileme alanı olarak belirlenmiştir. Illk etapta, 10.1 I.2006 tarihinde Beyoğlu Belediye Meclisi Kararı ile sadece dokuz yapı adasını kapsayan Tarlabaşı I. Etap Yenileme Projesinin uygulama usul ve esasları belirlenmiştir (Türkün ve Sarıoğlu, 2014: 270). Tarlabaşı aynı zamanda, Beyoğlu Sit Alanı içerisinde yer almaktadır. Bu nedenle, söz konusu kanuna dayanılarak yenileme alanı belirlendiğinde bölgenin bir kısmında 'yenilenerek koruma' uygulanırken, diğer kısımlarda Koruma Kanuna göre 'sadece koruma' uygulamaları ortaya çıkmışıı.

Bu yasanın uygulamalarında, devletin en üst karar verici makamı tarafından onaylanmak üzere hazırlanan yenileme alanı sınırlarının gözleme dayalı ve öznel verilerle çizilmesi, kentli hakları, kent yönetimi gibi alanlarda tartışma konusu olmuştur (Dinçer, 2010: 243). Kentsel Yenilenme Alanı ilanının bilimsel kriterlere dayanmayışı ve kolaylıkla kötüye kullanılmaya açık oluşu kanunun getirdiği sorunlardan biridir (Özden, 2006: 224). Alanın belirlenme kriterleri kanunda ve kanunun yönetmeliğinde açıklanmayarak, alanı ilk belirleyen kurumlar olan yerel yönetimlere bu konuda takdir yetkisi sunularak esneklik sağlanmıştır. Örneğin, Beyoğlu bölgesinde bu kanuna dayanılarak ilk kez 20 Şubat 2006 tarihinde yenileme alanlarının ilanıyla başlayan süreçte, aynı yıl içinde 5 farkı yenileme alanı daha ilan edilmiştir. Yenileme alanı ilan edilen yerlerin büyüklük ve konumlarının birbirlerinden oldukça farklı ol- 
duğu görülmektedir. Örneğin, Fatih ve Eminönü bölgesinde, yenileme alanlarının kıyılar ve kara surları boyunca konumlanırken, Süleymaniye tarihî miras alanı ve Kapalıçarşı'nın ise, merkezde yer almakta olduğu ve alanlarının büyük olduğu ifade edilmektedir (Dinçer, 20I0: 25I).

5366 sayılı yasada, imar planlarından bahsedilmemekte, sadece yenileme projelerine ilişkin açıklamalar bulunmaktadır (Özden, 20I3). Ayrıca, söz konusu kanunda, projeler ile alanda geçerli olan imar planları arasında da bir ilişki kurulmamış, koruma amaçlı imar planlarındaki gibi parsellerin işlevlerinin belirlenmesi amacı güdülmemiştir (Üstün, 20I4: 20I). Bu noktada kanun, proje temelli bir yaklaşım izleyerek, planlama sisteminde esneklik sağlanmıştır. Ancak, yapılacak kentsel yenileme projeleri ile var olan imar planında öngörülmeyen durumların ortaya çıkmasının hukuka aykırılık oluşturacağı açıktır. Birçok Danıştay kararında, mevcut imar planlarında öngörülen amaca aykırı olarak yapılan uygulamaların hukuka aykırı olduğu açıkça ifade edilmiştir (Üstün, 2014: 20I). Buradan da anlaşılmaktadır ki kanun, genel olarak bütünsel bir planlama anlayışından kopuk, planlama sürecinin doğal bir parçası olmayı reddeden, parçacıl çözümleri teşvik eden proje temelli bir yaklaşımı benimsemiştir (Özden, 2006: 225). Kanundaki düzenlemeler ayrıca avan proje kavramını öne çıkarmaktadır. Kanunun yönetmeliği, yenileme projenin onaylanmasının ardından avan projenin onayını getirmektedir. Böylelikle, yapılaşmaya dair kararlar da avan proje aşamasına bırakılmaktadır. Bu durum da yine planlama sisteminde esnekliği oluşturmaktadır.

Yasa, ayrıca yenileme uygulama projelerinin, yenileme avan projeleri esas alınarak hazırlanması gerektiğini hükme bağlamaktadır. Ancak, sit alanı içinde ilan edilen bir yenileme alanının sadece mimari avan proje ve uygulama projesi üzerinden tanımlanması, kent planlama ilkeleri açısından da sorunludur. Çünkü içeriği fiziki mekânının düzenlenmesi olarak sınırlandırılan, planlama disiplininden uzaklaştırılan ve plan dizgesinin dısına çıkarılan yenileme alanlarında, tarihi ve kültürel miras değerleri tehlike altına girmekte ve sosyo ekonomik dengelerin bozulmasına neden olmaktadır (Dinçer, 2010: 246). Mevcut uygulamalar, sit alanlarında koruma-yenileme ilişkisinin doğru bir şekilde kurgulanamadığını, yenileme uygulamalarının, alanın mevcut özgün dokusunu yeterince dikkate almadığını göstermektedir (Kentleşme Şurası, 2009: 295).

Bu kanun kapsamındaki; projelerin uygulama sürecinde, yenileme alanlarındaki yapıların boşaltılmasında ve yıkılmasında öncelikle anlaşma yolu esas alınmaktadır. Anlaşma sağlanamadığı takdirde, gerçek ve özel hukuk tüzel kişilerinin mülkiyetinde bulunan taşınmazlar için kamulaştırma yöntemi kullanılmaktadır. Ancak, kamulaştırma yapabilmek için kamu yararı kararı gereklidir, bu nedenle Bakanlar kurulunun kamu yararı kararı almasına dayanılarak kamulaştırma yapılabilir. Ancak yenileme alanı ilan edilen alanlarda mülkiyet sorunu sadece kamulaştır- ma boyutu ile açıklanamayan, daha fazla etkileri olan bir konudur. Yenileme alanı ilanından itibaren alanının gayrimenkul satış ve kira değerleri serbest piyasa fiyatları dışında yeni bir fiyat düzeyiyle tanışmaktadır (Türk ve Korthals Altes, 2010; Dinçer, 20 10: 245). Örneğin, Tarlabaşı Kentsel Yenileme uygulaması sonucunda yapılan ve satışa çıkan 360 Ofis Projesi'nde metrekare fiyatlarının 7.500 dolara ulaştığı bilinmektedir. Oysa ki bu projenin hemen yanındaki beş katlı ve tescilli bir binanın tümü 760.000 liraya (2012 yılı kuruna göre 420.000 USD) kamulaştırılmışıı. Bu durumda, binası kamulaştııılan bu kişi projeden 100 metrekarelik bir ofis bile alamayacak duruma gelmektedir (Türkün ve Sarıŏlu, 20|4: 285).

Diğer taraftan, söz konusu kanunun yönetmeliğinde olağan kamulaştırma sürecinin projenin uygulanmasında gecikmeye neden olacağının anlaşılması halinde, 2942 sayılı Kamulaştırma Kanunun olağanüstü durumlarda kullanılan 27. maddesi hükümlerine göre, 'acele kamulaştırma' yoluna gidilebileceği belirtilmiştir. Sürecin gecikmeye sebep olacağı hangi kriterler ile değerlendirileceği belirtilmemekte olup, kamulaştırma kararı için aranan kamu yararı kararından da bahsedilmemektedir. Böylelikle, yönetimlere acele kamulaştırma yoluna gitmek konusunda esneklik sağlanmaktadır.

Kanundaki düzenlemeler bütün olarak ele alındığında yenileme alanını, bütün bir proje alanı olarak değerlendiren bir yaklaşım ortaya çıkmaktadır. Bununla birlikte, yetkili idarenin uygun görmesi halinde ve projenin bütünlüğünün bozulmaması şartıyla yenileme alanı içindeki parsellerde tek başına yenileme projesi yapılabileceği belirtilmektedir. Ancak, bu yenileme projesinin giderleri, yapı izin süreçleri tanımlanmamaktadır. Ayrica vaktinde tamamlanmayan bireysel projelerin, proje bütünlüğünü korumak amacıyla yönetim tarafından tamamlanabileceği veya kamulaştırılabileceği hükmü getirilmiştir. Ancak burada, idarenin hangi durumlarda tamamlama seçeneğini veya kamulaştırma seçeneğini seçeceği tanımlanmayarak, idareye bu seçim konusunda da takdir yetkisi verilmiştir. Bu durum mülkiyet hakkı açısından değerlendirildiğinde, kişilerin kendi kararı ile mülkiyetleri üzerinde tasarruf yetkisi kısıtlanmakta, bireysel proje yapabilme hakkı yalnızca idarenin onayı ile olabilmektedir (Üstün, 20|4: 164).

Ayrıca söz konusu kanunda yenileme proje uygulamalarının, belediyeler ve kamu veya özel sektör kuruluşlarına yaptırılabileceği gibi TOKi ortaklığı ile de yapılabileceği belirtilmektedir. Ancak uygulama sırasında tüm kontrollerin ve denetimlerin belediye tarafından yapılacağı belirtilmektedir. Proje ortaklığı temelinde oluşan bu ilişkinin hangi esaslara göre şekilleneceği konusunda yasada ve yönetmelikte ayrıntılı bir düzenlemeye gidilmemesinden dolayı tekil uygulamalarda farklılık arz edebilecek bir esnekliğe kavuşmaktadır. Bununla birlikte, yenileme alanlarındaki uygulamaları her türlü vergi, resim, harç ve ücretlerden muaf tutması ile teşvik etmektedir. 
5393 Sayılı Belediye Kanunundan ve 5998 Sayılı Belediye Kanununda Değişiklik Yapılmasına İlişkin Kanundan Ortaya Çıkan Esneklikler

2005 yılında belediyenin görev, yetki ve sorumlulukları ile çalışma usûl ve esaslarını düzenleyen 5393 sayılı Belediye Kanunu Yerel Yönetim Reform çalışaları kapsamında yürütülen çalışmalardan biri olmuştur. Kanunun 73. maddesinde, belediyelerin kentsel yenilemeye yönelik rolleri ve yükümlülükleri tanımlanmış ve belediyeler kentsel yenilemenin yerel ayağı olarak uygulamaları yürütmeye başlamışlardır. 5393 Sayılı Belediye Kanundan önce yürürlükte bulunan 1580 sayılı Belediye Kanunu ve 3194 sayılı İmar Kanunları incelendiğinde, yenileme projelerinin uygulanması konusunun açık ifadeler ile tanımlanmadığı ve belediyelere yenileme projeleri ile ilgili yetki verilmediği görülmektedir. Ayrıca 5393 sayılı Belediye Kanununun öncesinde, belediyelerin deprem riskli alanlardaki yapılara müdahale etmesinde önemli kısıtlayıcıların bulunmakta olduğu bilinmektedir (Tarakçı ve Türk, 2015: 1558). 5393 sayılı Belediye Kanununun 73. maddesinde belediyelere kentsel dönüşüm alanı belirleme yetkisi verilmektedir. Ancak, özellikle uygulama araçları konusunda ayrıntıı bir bilgi verilmemiştir. Büyükşehir alanlarında ilçe belediyeleri bu yetkiyi kullanırken, büyükşehir belediyelerine kentsel yenileme projeleri konusunda yetki verilmemiştir. 2010 yllında ise söz konusu kanunun 73. maddesinde yapılan değişiklikler için 5998 sayılı Belediye Kanununda Değişiklik Yapılmasına Iliş̧kin Yasanın yürürlüğe girmesi ile, 73. maddenin kapsamı genişletilmiş hem kentsel dönüşüm hem de kentsel gelişim alanlarının belirlenmesi sağlanmıştır. Ayrıca bu yetkiler, büyükşehir belediyelerine de bu yetkiler verilmiştir. Kanunda hak sahibi olanlar ile anlaşma esaslı olarak uygulama yapılacak olup, anlaşma sağlanamayan hallerde kamulaşırıma devreye girmektedir. Kanuna göre gayrimenkul sahipleri ve 298 I sayılı Af Yasasına dayanılarak hak sahibi olmuş kişiler hak sahipleri olarak tanımlanmaktadır. 298I sayılı Kanun kapsamına girmeyen gecekondu sahiplerine ise, konut veya işyeri verilmesi hususu belediyenin takdirine bırakılmaktadır.

Bu yeni düzenlemeler ile kanunda, kentsel yenileme alanı olarak ilan edilecek alanın büyüklüğüün en az 5 en çok 500 hektar arasında olması, toplamı 5 hektardan az olmamak kaydı ile proje alanı ile ilişkili birden fazla yerin tek bir kentsel yenileme alanı olarak belirlenebileceği hükmü getirilmiştir. Ancak alan büyüklüğünün tespitine ilişkin kriterler belirlenmemiştir. Örneğin, İstanbul'da Maltepe ilçesinde 93 hektarlık alan Başıbüyük Mahallesi Kentsel Yenileme Alanı olarak ilan edilmiştir. Alanda, kentsel yenilemeye dair ilk çalışmalar 24.02.2006 tarihinde TOKi, İstanbul Büyükşehir Belediyesi ve Maltepe Belediyesi arasında imzalanan 'Istanbul Maltepe Kentsel Yenileme Projesine İlişkin Protokol' ile başlamıştır (Şen ve Türkmen, 20I4: 17I). Proje etaplar halinde TOKi tarafından yürütülmekte olup, süreç devam etmektedir. Kanun ile büyükşehir belediye sınırları içinde kentsel yenileme alanı ilan etme ve ilan edilen alandaki her ölçekteki imar planları yapma, parselasyon planı, bina inşa- at ruhsatı, yapı kullanma izni ve benzeri tüm imar işlemleri ile 3194 sayilı İmar Kanununda belediyelere verilen yetkileri kullanma yetkisi büyükşehir belediyelerine devredilmektedir. Buna dayanarak, 18.03.2017 tarihinde alana ilişkin nazım imar planı İstanbul Büyükşehir Belediye Meclisi tarafından onaylanmıştır.

5393 sayılı kanunda 2010 yılında 5998 sayılı Kanunla yapılan değişiklikler sonrasında, ilçe belediyelerinin kentsel yenileme alanlarındaki yetkileri azalmakta ve neredeyse tüm yetkiler büyükşehir belediyelerine geçmektedir. Örneğin, bu yasayla birlikte Ankara'daki kentsel yenileme alanlarının \%66'sı Ankara Büyükşehir Belediyesi'nde yetkisi altına girmiştir (Bektaş, 2014: 162). Burada, belediyelere, kentsel yenileme uygulamaları gerçekleştirmek amacıyla, imar mevzuatı ile getirilen bütünlüğü yok sayan, geniş bir takdire dayanan yetki verilmektedir. Anayasa Mahkemesi'nin 18.10.20I2 tarihli ve E: 20I0/82 ve K: $2012 / 159$ sayılı kararında 'dava konusu kurallarla belediyelere kentsel dönüşüm ve gelişim projeleri uygulama konusunda takdir yetkisi verilmesi bir gerekliliktir. Zira kentler sürekli değişen ve gelişen alanlar olduğundan, kentlerin her geçen gün değişen ihtiyaçlarının önceden belirlenmesinin güçlüğü nedeniyle, bu ihtiyaçların nasıl karşılanacağııın kanunlarda tüm detaylarıyla öngörülmesi mümkün değildir.' denilerek, takdir yetkisinin varlığı ve gerekliliği kabul edilmiştir.

Bektaş (2014) tarafından yapılan araştırmada Ankara'da 2004-20I4 yılları arasında ilan edilen kentsel yenileme alanları incelenmiş ve Ankara'nın toplam 80.000 ha yerleşik alanının yaklaşık yarısında kentsel yenileme alanları (96 adet) ilan edilmiştir. İlan edilen bu alanların \%26'ık dilimin 2005 yılında yoğunlaştı̆̆ı, \%। I'inin ise 2010 yılında 5998 sayılı kanunun yürürlüğe girmesi ile belirlendiği ifade edilmektedir. Kentsel yenileme alanlarının \% I8'i ise, 2013 yılında 6306 sayılı kanuna göre ilan edilmiştir, kentsel yenileme alanlarının geri kalan \%45'i ise diğer yıllarda belirlenmiştir.

Kentsel yenileme uygulamalarının planlamaya bir seçenek olmasının yanı sıra, belirlenen kentsel yenileme alanları, kentin yerleşik alanının yaklaşık yarıııdır (Bektaş, 20I4: 16I). Bu durum, Ankara gibi önemli bir kentin yarısının düzenleyici planlama sistemine göre, diğer yarısının takdire dayalı planlama sistemi ile planlanacağı anlamı taşımaktadır (Tarakci veTurk, 2017).

\section{Sayılı Afet Riski Altındaki Alanların Dönüştürülmesi Hakkında Kanundan Ortaya Çıkan Esneklikler}

2012 yılında 6306 sayılı Afet Riski Altındaki Alanların Dönüştürülmesi Hakkında Kanun kentsel yenileme adına önemli ve tartışmalı bir yasal araç olarak yürürlüğe girmiştir. Kanunun amacı; afet riski altındaki alanlar ile bu alanlar dışındaki riskli yapıların bulunduğu arsa ve arazilerde iyileştirme, tasfiye ve yenilemelere dair usul ve esasları belirlemektir. Kanun kapsamında riskli yapı riskli alan tanımı yapılmışır. Riskli alan; zemin 
yapısı veya üzerindeki yapılaşma sebebiyle can ve mal kaybına yol açma riski taşıyan, Bakanlık veya İdare tarafından belirlenen ve Bakanlı̆̆ın teklifi üzerine Bakanlar Kurulunca kararlaştırılan alandır. 02.07.2018 tarihli ve 700 sayılı KHK ile Bakanlar Kurulunun yetkisi Cumhurbaşkanı'na verilmiştir. Riskli yapı ise, riskli alan içinde veya dışında olup ekonomik ömrünü tamamlamış olan ya da yıkılma veya ağır hasar görme riski taşıdığı ilmî ve teknik verilere dayanılarak tespit edilen yapı demektir. Kanunla birlikte, 'riskli alanların' ve 'riskli yapıların' belirlenmesi ile ülkenin tüm afet riskli alanlarında var olan yapıların 'iyileştirilmesi', 'tasfiyesi' ve 'yenilenmesi' konularında yetki genel olarak Çevre ve Şehircilik Bakanlığı'na verilmekte olup, ancak Bakanlık tarafından görevlendirilmeleri halinde yerel yönetimlerce (belediyeler ve il özel idareleri) ya da TOKi tarafından kullanılabileceği düzenlenmiştir.

Birleşmiş Milletler ve Avrupa Konseyi tarafından hazırlanmış uluslararası hukuk metinlerinde ve Türkiye Cumhuriyeti Anayasa'nın 57. maddesinde, konut mevzuatı açısından devlete önemli görevler yüklenmektedir (Akıncı, 20l6). Devlet vatandaşlarının sağlıklı konutlarda yaşaması için gerekli tedbirleri almak zorundadır (Şimşek, 20 I5). 6306 sayılı yasa, sağlıklı ve güvenli yaşama çevrelerini oluşturmayı amaçlamaktadır. Bu gerekçeye dayanılarak, 6306 sayılı yasa ile merkezi yönetime geniş yetkiler verilmekte, verilen bu yetkiler ile hem planlamada, hem de uygulamada esneklikler sağlanmaktadır. Özel sektörün de (yüklenici firmalar) önemli ölçüde söz hakkı sahibi olduğu görülmektedir. Bununla birlikte, 6306 sayılı Yasa kapsamında belediyelerin yeterince rol oynadığı söylenememektedir. Oysaki, belediyeler, özel sektör ile hak sahipleri arasındaki uzlaşma süreçlerinde önemli bir role sahip olacağı açıktır. Yasadaki yaklaşım da ise, Bakanlığa ağırlık verilerek, yerel yönetimlerin kentsel yenileme uygulamalarındaki bu işlevinin engellenmesi yönündedir (Üstün, 20|4).

6306 sayılı yasada da önemli esneklikler bulunmaktadır. Bunlardan ilki, yasanın temelini oluşturan riskli alan, revzerv alan ve riskli yapı belirlenmesine yönelik kriterlere ilişkindir. 6306 sayılı kanuna göre, riskli yapı, gerçek anlamda tanımlanması mümkün olmamakla birlikte, bir takım somut ölçülere göre belirlenebilmektedir. Bununla birlikte, riskli alanların tespit edilmesindeki kriterler somut olarak belirlenmemiş, idarenin takdirine bırakılmıştır. Örneğin, İstanbul'da arazi fiyatlarının en yüksek olduğu Maslak-Büyükdere aksının yanında olan ve \%92'si gecekondudan oluşan Derbent Mahallesi (Şen ve Öktem Ünsal, 2014: 203) özellikle 2000'li yılların başından itibaren çözülemeyen kentsel yenileme sorunları ile dikkat çekmektedir. Çözüm olarak alan 2013 yılında Bakanlar Kurulu kararıyla 'riskli alan' ilan edilmiştir. Söz konusu riskli alan kararı, 2014 yılında, Danıştay I4. Dairesinin 09.04.2014 tarihli E: 2013/I445 K: 2014/448I sayılı kararı ile alanın 'teknik bir raporla değil gözlemsel genel bilgiler' ile riskli alan ilan edilidiği gerekçesi ile iptal edilmiştir. Sonrasında, 27.10.2016 tarihinde
6306 sayılı Kanunun Uygulama Yönetmeliğinde yapılan değişiklik ile riskli alan kavramı genişletilmiştir. Yapılan değişiklik ile riskli alan zemin yapısı veya üzerindeki yapılaşma sebebiyle can ve mal kaybına yol açmasının dışında kamu düzeni veya güvenliğinin olağan hayatı durduracak veya kesintiye uğratacak şekilde bozulduğu yerler; üzerindeki toplam yapı sayısının en az \%65'i imar mevzuatına aykırı olan veya yapı ruhsatı alınmaksızın inşa edilmiş olmakla birlikte sonradan yapı ve iskân ruhsatı alan yapılardan oluşan alanlar da eklenmiştir. Bu değişiklik üzerine, 03.0I.2017 tarihinde Bakanlar Kurulu kararı ile Derbent Mahallesi tekrar riskli alan olarak ilan edilmiştir.

İstanbul'da 2012-2018 yılları arasında Resmi Gazete'de ilan edilen riskli alanlar toplam 59 adet olmakla birlikte, bu alanların bir kısmı Derbent mahallesinde olduğu gibi Danıştay tarafından iptal edilmiş ve sonrasında yeniden riskli alan ilan edilmiştir. Aynı şekilde, yasada rezerv alanın taşıyacağı özellikler, riskli alan olması ya da risk taşımayan bir alan olması vb. gibi yasada açık olarak tanımlanmamış ve rezerv alanların belirlenmesi de idarenin takdirine bırakılmıştır. 13.08.20I2 tarihli ve 2012/3573 sayılı ile 24.02.2014 tarih ve 2014/6028 sayılı Bakanlar Kurulu Kararı ile Avrupa yakasında belirlenen alanda Çevre ve Şehircilik Bakanlığı yetkilendirilmiştir. Devamında ise, söz konusu alan Bakanlık tarafından rezerv alan olarak ilan edilmiştir. Rezerv alan, Avrupa Yakasında en çok Arnavutköy, Başakşehir, Avcılar ve Küçükçekmece ilçeleri olmak üzere I I ilçeyi kapsayan 34.700 hektarlık alandır. Rezerv alanın 7.600 hektarı 3. Havalimanı olup, 27.100 hektarı İstanbul için 'Çılgın Proje' olarak tanımlanan Kanal İstanbul Projesini kapsayan Yenişehir alanından oluşmaktadır.

Kanunla verilen esnekliklerden ikincisi; riskli alanlara, rezerv yapı alanlarına ve riskli yapıların bulunduğu taşınmazlara ilişkin her tür ve ölçekteki plan ve projeyi hem hazırlamaya, hem onaylamaya hem de denetçisi olmaya Bakanlığın yetkili kılınmış olmasıdır. Ayrıca riskli alanlardaki ve rezerv yapı alanlarındaki uygulamalarda faydalanılmak üzere Bakanlığa her tür ve ölçekteki planlama işlemlerine esas teşkil edecek standartları belirlemeye yetkisi verilmektedir. Bu durum, riskli ve rezerv alanlarda, özel kanunlar da dahil olmak üzere başta 3194 sayılı İmar Kanun ve yönetmeliklerle belirlenen uyulması zorunlu teknik ve sosyal altyapı standartlarına uyulmayabileceği anlamına gelmektedir. Riskli yapı, riskli alan ve rezerv alan tanımlarının aslında ne kadar geniş bir çerçeveyi kapsadığı düşünülürse, buradaki en büyük esneklik, Çevre ve Şehircilik Bakanlığı'na kentsel yenileme kapsamında her ölçekte planı yapabilme yetkisi ile sağlanmıştır.

Kanunla verilen yetkilerden oluşan esnekliklerden üçüncüsü, riskli alanlarda, riskli yapılarda ve rezerv yapı alanlarında yıkımdan önce paydaşların en az üçte iki çoğunluğu ile karar alınmasıdır. Söz konusu üçte iki oranının objektif verilere dayalı olmadığı yönünde eleştiriler getirilmektedir (Özsunay, 20I5). Bu noktada öncelikle üçte iki çoğunluğun sağlanması veya sağlana- 
Tablo I. Kentsel yenileme süreçlerine ilişkin kanunlarda aktörlerin dağııımı

\begin{tabular}{|c|c|c|c|c|}
\hline $\begin{array}{l}\text { Esnekliğin } \\
\text { şekillenmesi }\end{array}$ & 5104 sayılı kanunu & 5366 sayılı kanun & $\begin{array}{l}\text { 5393/5998 sayılı } \\
\text { kanunu }\end{array}$ & 6306 sayılı kanun \\
\hline Alanın belirlenmesi & Kanun & Belediye & Büyükşehir Belediyesi & Bakanlık \\
\hline Alanın onaylanması & Kanun & $\begin{array}{l}\text { Bakanlar Kurulu } \\
\text { (2018 yılı itibariyle } \\
\text { Cumhurbaşkanı) }\end{array}$ & Büyükşehir Belediyesi & $\begin{array}{l}\text { Bakanlar Kurulu } \\
\text { (20।8 yılı itibariyle } \\
\text { Cumhurbaşkanı) }\end{array}$ \\
\hline Mülkiyet değerleme & $\begin{array}{l}\text { Ankara Büyükşehir } \\
\text { Belediyesi }\end{array}$ & Belediye & Büyükşehir Belediyesi & Bakanlık \\
\hline Plan yapma yetkisi & $\begin{array}{l}\text { Ankara Büyükşehir } \\
\text { Belediyesi }\end{array}$ & Belirsiz & Büyükşehir Belediyesi & Bakanlık \\
\hline Proje yapma yetkisi & $\begin{array}{l}\text { Belediye } \\
\text { TOKi } \\
\text { Kamu-Özel ortaklığı }\end{array}$ & $\begin{array}{l}\text { İ Özel İdare } \\
\text { Belediye } \\
\text { Kamu-Özel ortaklığı }\end{array}$ & $\begin{array}{l}\text { Büyükşehir Belediyesi } \\
\text { TOKi } \\
\text { Özel Sektör }\end{array}$ & $\begin{array}{l}\text { Bakanlık } \\
\text { TOKi } \\
\text { Kamu-Özel ortaklığı }\end{array}$ \\
\hline Kamulaştırma & $\begin{array}{l}\text { Ankara Büyükşehir } \\
\text { Belediyesi }\end{array}$ & $\begin{array}{l}\text { İ Özel İdare } \\
\text { Belediye }\end{array}$ & Belediye & Bakanlık \\
\hline Acele kamulaştırma & Yok & Belediye & Yok & Bakanlık \\
\hline Mülkiyet dağıtımı & $\begin{array}{l}\text { Ankara Büyükşehir } \\
\text { Belediye Meclisi }\end{array}$ & Belediye Meclisi & Büyükşehir Belediyesi & Bakanlık \\
\hline Sosyal yapı & Soylulaştırma var & Soylulaştırma var & Soylulaştırma var & $\begin{array}{l}\text { Alansal ölçekte var } \\
\text { Bina ölçeğinde yok }\end{array}$ \\
\hline
\end{tabular}

maması olarak iki seçenek ortaya çıkmaktadır. Üçte iki çoğunluk sağlandığı takdirde karara katılmayanların bağımsız bölümlerine ilişkin arsa payları Bakanlık tarafından rayiç değeri dikkate alınarak diğer paydaşlara açık artırma usulü ile satılabilmekte, diğer paydaşlara satış gerçekleşmediği durumlarda ise Bakanlık tarafından satın alınabilmektedir. Üçte iki çoğunluk sağlanamadığı takdirde ise özel mülkiyetler Bakanlık, TOKI veya İdare tarafından acele kamulaştırmaya tabi olabilmektedir. Anayasa Mahkemesi'nin 27.02.20I4 tarihli E: 2012/87 K: 20I4/4I sayılı kararında "afet riski altındaki yerleşim merkezlerinin iskân durumunun yeniden düzenlenmesinin bir parçası olarak malikleri tarafından kendi iradeleriyle değerlendirilmeyen taşınmazların, ilgili kamu kurum ve kuruluşları tarafından kamulaştırma yoluyla değerlendirilmesinde kamu yararı bulunduğu" ifade edilmektedir. Anayasa Mahkemesinin kararına ve kanunun bütününe bakıldığında yapılacak işler ile ilgili sürecin hızlandırılmasının arzu edildiği, bu nedenle de olağan düzenden ayrıldığı anlaşılmaktadır. Ancak, buradaki en temel konu çoğunluğa katılmayan paydaşların paylarının ellerinden alınması zorunluluğudur. Bu durum, karara katılmayan paydaşların o topluluğun dışına itilmesine neden olabilmektedir (Kürşat, 20I3: 3I).

Kanunla verilen yetkilerden oluşan esnekliklerden dördüncüsü, anlaşma ile tahliye edilen yapıların maliklerine veya malik olmasalar bile kiracı veya sınırlı ayni hak sahibi olarak ikamet edenlere veya bu yapılarda işyeri bulunanlara geçici konut veya işyeri tahsisi yada kira yardımı yapılabileceğine ilişkindir. Kuralda 'yapılabilir' ibaresine yer verilerek ilgili kurum ve kuruluşlara belirtilen sınırlar dahilinde takdir yetkisi tanınmaktadır (Tarakçı ve Türk, 2017). 6306 Sayılı Kanunun Uygulama Yönetmeliğine göre kira yardım süresi riskli yapılarda 18 ay olup, riskli ve rezerv yapı alanlarında 48 ayı geçmemek şartı ile ilgili kurumca belirlenmektedir. Kira yardımı ile ilgili bulunan birçok belirsizliği gidermek üzere Çevre ve Şehircilik Bakanlığı tarafından 2019 yılında Kira Yardımı Kılavuzu yayınlanmıştır. Buna göre riskli yapılarda Konut/işyeri maliklerine 18 ay, kiracılara 2 ay, sınırlı ayni hak sahiplerine 5 ay süreyle kira yardımı yapılmaktadır. Bakanlığın 17 Ağustos 2020 tarihinde yayınladığı rapora göre 2012-2020 yılları arasında toplam 35I.260 hak sahibine kira yardımı yapılmıs olup, en fazla kira yardımı yapılan iller sırasıyla İstanbul, Ankara, Elazığ, Antalya ve İzmir olmuştur (https://csb.gov.tr/yilin-ilk-yarisinda-307-milyonkira-yardimi-yapildi-bakanlik-faaliyetleri-29798).

\section{Değerlendirme ve Sonuç}

Türkiye, düzenleyici planlama sistemine sahip olmakla birlikte (Özkan ve Türk, 20l6: 36), kentsel yenileme ile ilgili kanunlar ile plan yaklaşımında daha çok proje yaklaşımı öne çıkaran sistem benimsenmektedir. Ayrıca, kanunlarda gerek merkezi yönetime gerekse de yerel yönetime verilen takdir yetkileri ile takdire dayalı bir planlama yaklaşımı da benim- 
Tablo 2. Kentsel yenileme ile ilgili kanunlarda esnekliklerin şekillenmesi

\begin{tabular}{|c|c|c|c|c|}
\hline & 5104 sayılı kanunu & 5366 sayılı kanun & $5393 / 5998$ sayılı kanunu & 6306 sayılı kanun \\
\hline \multirow{3}{*}{ 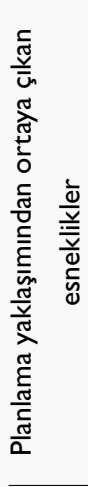 } & $\begin{array}{l}\text { Alan sınırları içerisinde } \\
\text { parçacıl plan yapılmaktadır. }\end{array}$ & $\begin{array}{l}\text { Plan yapımından } \\
\text { bahsetmemektedir. }\end{array}$ & $\begin{array}{l}\text { Alan sınırları içerisinde } \\
\text { parçacıl plan yapılmaktadır. }\end{array}$ & $\begin{array}{l}\text { Alan sınırları içerisinde } \\
\text { parçacıl plan yapılmaktadır. }\end{array}$ \\
\hline & $\begin{array}{l}\text { Her ölçekteki imar planını } \\
\text { yapma yetkisi Ankara } \\
\text { Büyükşehir Belediyesi'ne } \\
\text { verilmektedir. } \\
\end{array}$ & $\begin{array}{l}\text { Plan yapma yetkisinden } \\
\text { bahsetmemektedir. }\end{array}$ & $\begin{array}{l}\text { Her ölçekteki imar planlarını } \\
\text { yapmaya Büyükşehir } \\
\text { belediyesi yetkilidir. }\end{array}$ & $\begin{array}{l}\text { Her tür ve ölçekteki plan } \\
\text { ve projeyi yapmaya Bakanlık } \\
\text { yetkilidir. }\end{array}$ \\
\hline & & $\begin{array}{l}\text { Yenileme uygulama projeleri, } \\
\text { yenileme avan projeleri esas } \\
\text { alınarak hazırlanabilecektir. }\end{array}$ & & $\begin{array}{l}\text { Her tür ve ölçekteki planlama } \\
\text { işlemlerine esas teşkil edecek } \\
\text { standartları belirlemeye } \\
\text { Bakanlık yetkilidir. }\end{array}$ \\
\hline \multirow{4}{*}{ 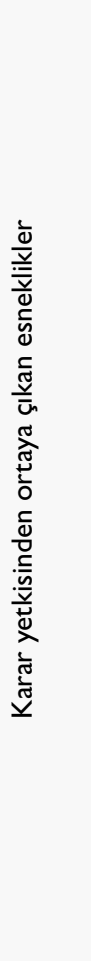 } & $\begin{array}{l}\text { Alan sınırları kanunun } \\
\text { ekindeki krokide } \\
\text { belirlenmektedir. }\end{array}$ & $\begin{array}{l}\text { Alanın belirlenme kriterleri } \\
\text { açıklanmamaktadır. }\end{array}$ & $\begin{array}{l}\text { Alanın belirlenme kriterleri } \\
\text { açıklanmamaktadır. }\end{array}$ & $\begin{array}{l}\text { Riskli alan, revzerv alan ve } \\
\text { riskli yapı belirlenmesine } \\
\text { yönelik kriterler } \\
\text { bilimsel verilere göre } \\
\text { açıklanmamaktadır. }\end{array}$ \\
\hline & $\begin{array}{l}\text { Yapılan proje, malikler ve } \\
\text { hak sahipleri ile yapılan } \\
\text { anlaşmalar çerçevesinde } \\
\text { uygulanmaktadır. }\end{array}$ & $\begin{array}{l}\text { Yenileme alanlarındaki } \\
\text { yapıların yıkılmasında } \\
\text { öncelikle anlaşma yolu esastır. }\end{array}$ & $\begin{array}{l}\text { Alanda öncelikle anlaşma yolu } \\
\text { esastır. }\end{array}$ & $\begin{array}{l}\text { Yıkım olduktan sonra } \\
\text { paydaşların en az üçte } \\
\text { iki çoğunluğu ile karar } \\
\text { alınabilmektedir. }\end{array}$ \\
\hline & $\begin{array}{l}\text { Anlaşma sağlanamayan } \\
\text { hallerde gayrimenkuller } \\
\text { belediye tarafından } \\
\text { kamulaştırılabilmektedir. }\end{array}$ & $\begin{array}{l}\text { Anlaşma sağlanamadığı } \\
\text { takdirde, kamulaştırma } \\
\text { yöntemi kullanılmaktadır. }\end{array}$ & $\begin{array}{l}\text { Anlaşma sağlanamayan } \\
\text { hallerde gayrimenkuller } \\
\text { belediye tarafından } \\
\text { kamulaştırılabilmektedir. }\end{array}$ & $\begin{array}{l}\text { Anlaşma sağlanamaması } \\
\text { halinde, özel mülkiyetler } \\
\text { Bakanlık, TOKI veya } \\
\text { İdare tarafından acele } \\
\text { kamulaştırılabilmektedir. }\end{array}$ \\
\hline & $\begin{array}{l}\text { Hak sahipliği için gerekli } \\
\text { olan büyüklükleri ve Proje } \\
\text { sonunda hak sahiplerine } \\
\text { verilecek konutların } \\
\text { niteliklerini belirlemeye } \\
\text { belediye meclisi yetkilidir. }\end{array}$ & $\begin{array}{l}\text { Yenileme proje } \\
\text { uygulamalarının, belediyeler } \\
\text { ve kamu veya özel sektör } \\
\text { kuruluşlarına yaptırılabileceği } \\
\text { gibi TOKI ortaklığı ile de } \\
\text { yapılabileceği belirtilmektedir. }\end{array}$ & $\begin{array}{l}\text { Hak sahiplerine mülkiyet } \\
\text { dağılımında belediye yetkilidir. }\end{array}$ & $\begin{array}{l}\text { Anlaşma ile tahliye edilen } \\
\text { yapıların maliklerine/ } \\
\text { kiracılara /sınırlı ayni hak } \\
\text { sahibi olanlara kira yardımı } \\
\text { yapılabilmektedir. }\end{array}$ \\
\hline
\end{tabular}

senmektedir. Bu makalenin amacı, kentsel yenileme ile ilgili yasal düzenlemeler ile ortaya çıkan esneklik ve sonuçları$\mathrm{n}$, kentsel yenileme uygulamaları üzerinden analiz etmektir. Tablo I'de kentsel yenileme ile ilgili kanunlarda aktörlerin dağılımında yerel yönetimlerden merkezi yönetime doğru bir yönelme olduğu görülmektedir.

Türkiye'de 2004'ten günümüze kadar ortaya çıkan kentsel yenileme ile ilgili yasal araçlara bağlı olarak ortaya çıkan esnekliğin derecesi ve içeriği zaman içinde değişim göstermiştir. $\mathrm{Bu}$ durum, planlama sistemi içerisinde değerlendirildiğinde, planlama sisteminin düzenleyici planlama sistem iken, kentsel yenileme alanları için çıkarılan kanunlarla, takdire dayalı bir sisteme evrildiği ortaya çıkarmaktadır. Kentsel yenileme uygulamalarında plan temelli sistemden çıkılarak, proje temelli bir yaklaşım benimsenmiştir. Özellikle kanunlarda geçen 'avan proje' kavramı ile planlama sisteminde delikler açılmaktadır. Yenileme alanlarında avan projeye göre uygulama yapılacağı ibaresi, hem yapı yükseklikleri hem de nüfus yoğunluğuna dair bir kısıtlama getirilmemesi, tasarım kriterlerini büyük ölçüde geliştiricinin belirlemesini sağlamıştır (Özkan ve Türk, 2016: 4I). Ayrıca avan proje uygulamaları ile sosyal ve teknik altyapı alanlarının yerseçimi de yapılarak, planın işlevi ortadan kaldırılmaktadır (Tarakçı ve Türk, 2019). Oysa, Türkiye'de mevcut planlama anlayışında bu belirlemeler çok kesin bir biçimde yapılmaktadır. Plan kararları ile imar haklarının gelişti- 
riciyi yönlendirmeksizin serbest bırakılması, kentsel yenileme proje alanlarının yakın çevresinde yer alan konut alanlarının dokusundan bağımsız gelişmesine neden olmuştur. Çünkü söz konusu planlar parçacıl olarak yapılmaktadır. Diğer taraftan planların hazırlanması ve onaylanmasından başlayarak yapı izin denetimine kadar yetkinin çok parçalanmış olması ve kontrol sürecinin yetersizliği denetimsizliğe neden olmaktadır.

Diğer taraftan, kentsel yenileme alanının belirlenmesinden başlayarak, hak sahipliğinin tanımlanmasında yönetimlere önemli ölçüde takdir yetkisi verilmektedir. Kentsel yenileme süreci içerisinde, söz konusu takdir yetkilerinin önce belediyelere verildiği sonra büyükşehir belediyelerine devredildiği ve en sonunda merkezi yönetime aktarıldığı görülmektedir. Özellikle, son yasal düzenlemeler ile daha önceden yerel yönetimde olan yetkilerin merkezi yönetime alındığı, neredeyse tüm kentsel yenileme alanlarının merkezi yönetim tarafından yönetildiği, belirlendiği, planlandığı ortaya çıkmaktadır. Örneğin, Ankara'da yapılan araştırmalara göre 6306 sayılı kanuna göre belirlenen riskli alanların \%94'lük bir kısmının önceden 5393 sayılı Belediye Kanunun 73. maddesi uyarınca kentsel yenileme alanı ilan edilen bölgelerde olduğu tespit edilmiştir (Bektaş, 2014: 165). Bu göstermektedir ki, kentsel yenileme alanlarının niteliği, gerekçesi değişmeyerek merkezi yönetimin kendine aldığı takdire dayalı geniş yetkilerden yararlanılmaktadır. Tablo 2'de kentsel yenileme ile ilgili kanunlarda esnekliklerin zaman içerisinde kapsamında olan genişleme görülmektedir. Özellikle son yasal düzenlemeler ile daha önceden yerel yönetimde olan yetkilerin merkezi yönetime alındığı, neredeyse tüm kentsel yenileme alanlarının merkezi yönetim tarafından yönetildiği, belirlendiği, planlandığı ortaya çıkmaktadır. Diğer taraftan ise, takdire dayalı planlama sistemlerinde temel olan, görüşme ve uzlaşma süreçleri ise, kanunlarda tanımlanmamıştır. Tüm kanunlarda 'anlaşma esastır' denilmekle birlikte, anlaşmanın şartları ve süreçlerine yönelik açıklama getirilmemiştir. Anayasa Mahkemesi'nin 27.02.20I4 tarihli E: 20I2/87 K: 20I4/4I sayılı kararından da anlaşıldığı gibi hem söz konusu takdir yetkisi hem planlama sistemine getirilen proje temelli yaklaşım makul bulunmaktadır.

Kentsel yenileme uygulamalarında gerek proje temelli yaklaşımdan, gerekse karar yetkisinden gelen esneklikler değerlendirildiğinde; her ikisinde de idarelerin takdir yetkisinin genişletildiği, genişletilen takdir yetkilerinin ise özel sektör için önemli yararlar sağladığı açıktır. Yapılan esneklik müdahalelerinin çoğu özel sektörün kazancını arttırıcı, süreci hızlandırıcı ve maliyetlerini düşürücü niteliktedir. Bu durum, gayrimenkul sektörünün Türkiye ekonomisinde önemli bir unsur yapılmasına yönelik yaklaşımlarla örtüşmektedir. Diğer taraftan, kentsel yenileme ile ilgili yasal kaynaklardan doğan esneklikler sonucunda, özellikle gecekondu bölgeleri ve tarihi kent merkezlerindeki kiracıların, mülk sahiplerinin maddi ve manevi olarak zarar gördüğü ortaya çıkmaktadır.
Kent sorunlarının farklılı̆̆ı, kentsel yenileme uygulamarında farklı senaryo ve farklı yöntemler uygulanmasını gerektirmektedir. Bu durumda, farklı kentler ve durumlar için özel düzenlemeler yapılması yerindedir. Ancak uygulamalardaki usul, süre, bireylere uygulanacak sınırlamalar, plan ve projelerin üst planlarla olan ilişkileri bakımından genel bir düzenleme yapılması gerektirmektedir. Aksi takdirde, idare sınırsız bir takdir yetkisine sahip olabileceği gibi, farklı kanunlarla benzer durumlar için farklı çözümler oluşturulabilecek ve Anayasal ilke olan eşitlik ilkesi zarar görmesi muhtemeldir (Üstün, 2014: 227). 


\section{KAYNAKLAR}

Akıncı, M. (2016). Kentsel Dönüşümün Asıl Hedefi Olarak Elverişli Konut Hakkı ve İdarenin Ödevleri. Legal Hukuk Dergisi, 14, 6643-6680.

Alfasi, N. (2006). Planning policy? Between long-term planning and zoning amendments in the Israeli planning system. Environment and Planning A, 38, 553-568.

Balaban, O. (2012). The Negative Effects of Construction Boom on Urban Planning and Environment in Turkey: Unraveling the Role of the Public Sector. Habitat International, 36(1), 26-35.

Bektaş, Y. (2014). Bir Kentleşme Stratejisi Olarak Yasanın Kentsel Mekanı Dönüştürmedeki Etkisi: Ankara Örneği. Planlama Dergisi, 3(24), 157 172.

Booth, P. (1996). Controlling development Certainty and discretion in Europe, the USA and Hong Kong. London: Taylor \& Francis.

Buitelaar, E., \& Sorel, N. (2010). Between the rule of law and the quest for control: Legal certainty in the Dutch. Land Use Policy(27), 983-989. Ocak 2017 tarihinde alınd

Demir, A. M. (2009). İmar Planı Değişikliklerinin Değerlendirilmesi Zeytinburnu Örneği. İstanbul: İstanbul Teknik Üniversitesi Fen Bilimleri Enstitüsü.

Dinçer, İ. (2010). Türkiyéde Kent Ölçeğinde Koruma ve Kent Planlamanın Yollarının Kesişmesi ve Yeniden Ayrılması: Protokol Alanından Yenileme Alanına. D. Özdemir içinde, Kentsel Dönüşümde Politika, Mevzuat ve Uygulama, Avrupa Deneyimi, İstanbul Uygulamaları (s. 225-255). Ankara: Nobel Yayınevi.

Dinçer, İ. (2011). The Impact of Neoliberal Policies on Historic Urban Space: Areas of Urban Renewal in Istanbul. International Planning Studies, 16(1), 43-60.

Ergün, N. (2006). Gentrification Kuramlarının İstanbul'da Uygulanabilirliği. D. Behar, \& T. İslam içinde, İstanbul'da Soylulaştırma Eski Kentin Yeni Sahipleri. İstanbul: İstanbul Bilgi Üniversitesi Yayınları.

Ersoy, M. (2000). İmar Planlarının Kademelenmesi ve Farklı Ölçeklerdeki Planlar Arasındaki İlişki. M. Ersoy, \& Ç. Keskinok içinde, Mekan Planlama ve Yarg1 Denetimi. Ankara: Yarg1 Yayınevi.

Gedikli, B. (2004). Strategic Spatial Planning and Its Implementation in Turkey: Şanlıurfa Provincial Development Planning Case. Ankara: Orta Doğu Teknik Üniversitesi.

Genç, F. (2014). Gecekonduyla Mücadeleden Kentsel Dönüşüme Türkiyéde Kentleşme Politikaları. Adnan Menderes Üniversitesi Sosyal Bilimler Enstitüsü Dergisi, 1(1), 15-30.

Gür, S., \& Türk, Ș. Ș. (2014). 6306 Sayılı Kanunla Yeniden Ortaya Çıkan Bina Ölçeğinde Kentsel Yenileme Pratiği: Bağclar İlçesi Örneği. 38. Dünya Şehircilik Günü Kolokyumu (s. 623-650). İstanbul: TMMOB Sehir Planciları Odası.

Güzey, Ö. (2016). The last round in restructuring the city: Urban regeneration becomes a state policy of disaster prevention in Turkey. Cities(50), 40-53.

Heurkens, E., \& Hobma, F. (2014). Private Sector-led Urban Development Projects: Comparative Insights from Planning Practices in the Netherlands and the UK. Planning Practice and Research, 29(4), 350-369.

JICA. (2002). Afet Önleme/Azaltma Temel Planı. İstanbul: İstanbul Büyükşehir Belediyesi.

Karaman, O. (2013). Urban Renewal in Istanbul: Reconfigured Spaces, Robotic Lives. International Journal of Urban and Regional Research, 37(2), 715-733.

Keleş, R. (2020). Kentleşme Politikası (17 b.). Ankara: İmge Kitapevi.

Kentleşme Şurası. (2009). Komisyon Raporları (Cilt 1). Ankara: Bayındırlık ve İskan Bakanlığı.

Köktürk, E., \& Köktürk, E. (2007). Türkiyéde Kentsel Dönüşüm ve Almanya Deneyimi. 11. Türkiye Harita Bilimsel ve Teknik Kurultayı. Ankara: TMMOB Harita ve Kadastro Mühendisleri Odası.

Kuyucu, T., \& Ünsal, Ö. (2010). 'Urban Transformation' as State-led Property
Transfer: An Analysis of Two Cases of Urban Renewal in Istanbul. Urban Syudies, 47(7), 1479-1499.

Kürşat, Z. (2013). 6306 Sayılı Afet Riski Altındaki Alanların Dönüştürülmesi Hakkında Kanunun Özel Hukuk Alanındaki Etkileri. M. Yasin, \& C. Şahin içinde, Kentsel Dönüşüm Hukuku (s. 19-48). İstanbul: İstanbul Üniversitesi S.S. ONAR İdare Hukuku ve İlimleri Araştırma ve Uygulama Merkezi Yayınları.

Kütük İnce, E. (2006)., Kentsel Dönüsümde Yeni Politika, Yasa ve Eğilimlerin Degerlendirilmesi “Kuzey Ankara Girişi (Protokol Yolu) Kentsel Dönüsüm Projesi. Ankara: Gazi ÜNiversitesi Fen Bilimleri Enstitüsü.

Munoz Gielen, D., \& Tasan-Kok, T. (2010). Flexibility in Planning and the Consequences for Public-value Capturing in UK, Spain and the Netherlands. European Planning Studies, 18(7), 1097-1131.

Orta, E. (2005). İmar Hukukunda Plan Hiyerarşisi ve Planların Çatışması. İstanbul: Legal Yayınevi.

Özden, P. P. (2006). Türkiye'de Kentsel Dönüşümün Uygulanabilirliği Üzerine Düşünceler. İ.Ü. Siyasal Bilgiler Fakültesi Dergisi(35), 215-233.

Özden, P. P. (2010). Türkiyedde Kentsel Dönüşüm Politikaları ve Mevzuat1na Eleștirel Bir Bakış. D. Özdemir içinde, Kentsel Dönüșümde Politika, Mevzuat ve Uygulama, Avrupa Deneyimi, İstanbul Uygulamaları (s. 196224). Ankara: Nobel Yayınevi.

Özden, P. P. (2013). Üst Ölçekli Planlamadan Projeci Yaklaşıma Planlamanın Değişen Yüzü. K. Eyüpgiller, \& Z. Eres içinde, Mimari ve Kentsel Koruma / Prof. Dr. Nur Akın'a Armağan (s. 435-455). İstanbul: YEM Yayın.

Özkan, H. A. (2012). Planlama Sistemlerinde Esneklik Kavramı: Türkiye Üzerine Bir Analiz. İstanbul: İstanbul Teknik Üniversitesi Fen Bilimleri Enstitüsü.

Özkan, H., \& Türk, Ş. (2016). Emergence, formation and outcomes of flexibility in Turkish planning practice. IDPR, 38, 25-54.

Özsunay, E. (2015). 6306 Sayılı Kanun ve Kentsel Dönüșüm Uygulamalarına İlişkin Düşünceler. İstanbul: Vedat Kitapçllı.

Rivolin, U. J. (2008). Conforming And Performing Planning Systems İn Europe: An Unbearable Cohabitation. Planning, Practice \& Research, 23(2), $167-186$

Seçkin, S., \& Üstün, G. (2015). İdari İşlemlerde Takdir Yetkisi ve Gerekçe İlkesi. Prof. Dr. Mehmet Akif Aydın'a Armağan - Hukuk Araştırmaları Dergisi, 509-533.

Steele, W., \& Running, K. (2012). Flexibility Versus Certainty: Unsettling The Land-Use Planning Shibboleth İn Australia. Planning, Pratice \& Research, 27(2), 155-176.

Şen, B., \& Öktem Ünsal, B. (2014). Derbent- Memeleketin İşçi Mahallesi ya da Küresel Kentin "Hukuksuz" Gecekondu Alanı. A. Türkün içinde, Mülk, Mahal, İnsan - İstanbul'da Kentsel Dönüşüm (s. 189-225). İstanbul: İstanbul Bilgi Üniversitesi Yayınları.

Şen, B., \& Türkmen, H. (2014). Başıbüyük- Bir Kentsel Dönüşüm Sınaması. A. Türkün içinde, Mülk, Mahal, İnsan - İstanbul'da Kentsel Dönüșüm (s. 143-188). İstanbul: İstanbul Bilgi Üniversitesi Yayınları.

Şimşek, S. (2015). Türkiyéde Kentsel Dönüşüm Uygulamaları. Ankara: Seçkin Yayıncilik.

Tarakci, S., \& Turk, S. S. (2017). Flexibility in Urban Renewal Practices: The Case of Turkey. AESOP Annul Congress, (s. 2538-2552). Lizbon.

Tarakçı, S., \& Türk, Ş. (2015). İstanbul'da Deprem Riskinin Azaltilmasi Gerekçesine Dayali Kentsel Yenileme Uygulamalari. 8. Ulusal Deprem Mühendisliği Konferansı, 11 Mayıs-14 Mayıs, 2015. 2, s. 1555-1573. İstanbul: TMMOB Harita Mühendisleri Odası.

Tarakçı, S., \& Türk, Ş. Ş. (2019). Türkiyéde Kentsel Yenileme Projelerinde Artan Değerin Kazanımında Plan Notunun Kullanımı - Fikirtepe Örneğı. 4. Uluslararası Kent Araştırmaları Kongresi. Ankara.

Tasan-Kok, T. (2006). Küresel Bütünleşme Sürecinde Kurumsal ve Mekânsal Değişim: Budapeşte, İstanbul ve Varşova Örnekleri. A. Eraydın içinde, Değişen Mekan Mekânsal Süreçlere İlişkin Tartışma ve Araştırma Toplu Bakıș: 1923-2003 (s. 307-339). Ankara: Dost Kitapevi Yayınları. 
Tasan-Kok, T. (2008). Changing Interpretations Of'Flexibility' In The Planning Literature: From Opportunism To Creativity? International Planning Studies, 13(3), 183-195.

Türk, S. S., \& Korthals Altes, W. K. (2010). Institutional Capacities in the Land Development for Housing on Greenfield Sites in Istanbul. Habitat International, 34, 183-195.

Türkün, A., \& Sarığlu, A. (2014). Tarlabaşı - Tarihi Kent Merkezlerinde Yoksulluk ve Dışlanan Kesimler Üzerinden Yeni Bir Tarih Yazılıyor. A. Türkün içinde, Mülk, Mahal, İnsan - İstanbul'da Kentsel Dönüşüm (s. 267-308). İstanbul: İstanbul Bilgi Üniversitesi Yayınları.

Uzun, N. (2015). İstanbul'da Seçkinleştirmenin Üç Aşaması: Cihangir, Galata ve Tarlabaşı Üzerinnden Bir Değerlendirme. B. Duman, \& İ. Coşkun içinde, Neden Nasıl ve Kim İçin Kentsel Dönüşüm (s. 431-451). İstanbul: Litera Yayıncilik.

Ünal, Y. (2015). Türk Şehir Planlama Hukukunun Dünü-Bugünü 19852015. İstanbul: Legal Yayıncilık.

Ünlü, T. (2006). Kentsel Mekânda Değişimin Yönetilmesi. METU Journal of the Faculty of The Architecture, 23(2), 63-92.

Ünlü, T. (2009). Mekansal Planlamanın Kentin Biçimlenmesine Etkisi: Mersin Örneği. Planlama Dergisi, 3(4), 27-42.

Üstün, G. (2014). Kentsel Dönüşüm Hukuku. İstanbul: On İki Levha Yayincilik.

Valtonen, E., Falkenbach, H., \& Viitanen, K. (2017). Development-led planning practices in a plan-led planning system: empirical evidence from Finland. European Planning Studies, 25(6), 1053-1075.

Yayla, Y. (1990). İdare Hukuku-I. İstanbul: Filiz Kitabevi. 